\title{
非 $\mathrm{A}$ 非 $\mathrm{B}$ 型肝炎および血液疾患児における $\mathrm{C}$ 型 肝炎ウイルス抗体と RNA ゲノムの保有率
}

\author{
小川哲史, 設楽利二, 外松学 \\ 由上伸一郎, 伊 藤賢, 友 政剛 \\ 群馬大学医学部小児科学教室（主任：黒梅恭芳教授)
}

(平成 2 年 12 月 27 日受付)

\begin{abstract}
要 旨: 非 $\mathrm{A}$ 非 $\mathrm{B}$ 型肝炎および輸血既往のある血液疾患の小児例について HCV ウイルス抗体 $(\mathrm{C} 100$ 3 ペプタイドに対する抗体）とRNA ゲノムを測定しその保有状況を検討した。11例の非 A 非 B 型肝炎 患児の検討では抗体陽性率 $18.2 \%$ と低值であったが，輸血例に限定すると $66.6 \%$ であった。輸血既往の ある血液疾患児39例の検討では抗体とゲノムの不一致が多くみられた。
\end{abstract}

Key words：C型肝炎, C100-3, 非A非B型肝炎, 輸血

(北関東医学 41 (2) : 341 344, 1991)

\section{I 緒言}

1989年に米国の Chiron 社のグループはC 型肝炎 ウイルスと思われる遺伝子に対する cDNA のク ローニングに成功し1),さらにこのクローンから合 成したペプタイド (C100-3) に対する抗体 ( HCV 抗 体）を検出する方法を開発した ${ }^{2}$. HCV 抗体は，す でに成人の非 A 非B型肝炎においては高い陽性率を 示すことが報告されている3 . また本年になり Polymerase Chain Reaction 法によって RNA ゲノムを 直接検出する方法が開発され, 現在その有用性が検 討されつつある. 今回我々は小览例において非 A非 B 型肝炎及び輸血既往のある血液疾患例を対象に C 型肝炎ウイルス抗体およびRNA ゲノムを測定しそ の保有状況を検討したので報告した。

\section{II 対象および方法}

対象は臨床経過などから診断された非 $\mathrm{A}$ 非 $\mathrm{B}$ 型肝 炎の小児 11 例 (男児 6 例, 女児 5 例, 年齢は 1 力月 から 6 歳で平均 2.3 歳) および輸血既往のある血液疾 患の小児39例（男児23例，女児16例，年齢は 3 力月 から17歳で平均8.5歳)の計50例である. 非 A 非 B 型 肝炎例は $\mathrm{A}$ 型肝炎, $\mathrm{B}$ 型肝炎, サイトメガロウイル ス感染，EB ウイルス感染はいずれも否定されてお
り，また11例中 3 例に輸血の既往があった．輸血既 往のある血液疾患児例では39例中 25 例にトランスア ミナーゼの上昇を認めた。ただし，これらは非 $\mathrm{A}$ 非 B型肝炎例には含めなかった。

$\mathrm{HCV}$ 抗体は非 $\mathrm{A}$ 非 B 型肝炎11例, 血液疾患39例 の計50例, RNA ゲノムは前者11例, 後者23例の計 34 例で測定した。測定は業者（BML，東京）に依頼し て行った.

$$
\text { III 結果 }
$$

\section{1) 非 $A$ 非B 型肝炎例}

11例の対象中, HCV 抗体陽性, RNA ゲノム陽性 が 2 例, 両者陰性が 9 例であった。輸血歴のある 3 例では輸血後 $1 \sim 2$ 力月で肝機能の異常がみられ, その1.5２5力月後（平均10力月後）に検査を行い, 2 例で HCV ウイルス抗体，RNA ゲノムともに陽 性，1例で両者陰性であった(表 1 および図 1 )。輸 血歴のない 8 例では肝機能の異常が認められてから 3 週〜 17 月後, 平均 6 力月で検查を行い全例で抗 体，ゲノムともに陰性であった（表 1 および図 2 ).

\section{2 ) 輸血既往のある血液疾患例}

$\mathrm{HCV}$ 抗体は39例中 2 例で陽性 (5.1\%), RNA ゲ ノムは23例中 5 例で陽性（21.7\%）であった．抗体 およびゲノムの両者を測定できた 23 例を肝機能異常

論文別刷請求先 $\overline{7} 371$ 前橋市昭和町三丁目 39-22 群馬大学医学部小児科学教室 小川哲史 
表 1

輸血歴あり：3例

\begin{tabular}{l|c|c}
\hline & HCV 抗体 (+) & HCV 抗体 $(-)$ \\
\hline RNA ゲノム $(+)$ & 2 & 0 \\
\hline RNA ゲノム $(-)$ & 0 & 1 \\
\hline
\end{tabular}

輸血歴なし：8 例

\begin{tabular}{l|c|c}
\hline & HCV 抗体 $(+)$ & HCV 抗体 $(-)$ \\
\hline RNA ゲノム $(+)$ & 0 & 0 \\
\hline RNA ゲノム $(-)$ & 0 & 8 \\
\hline
\end{tabular}

経過（輸血例）

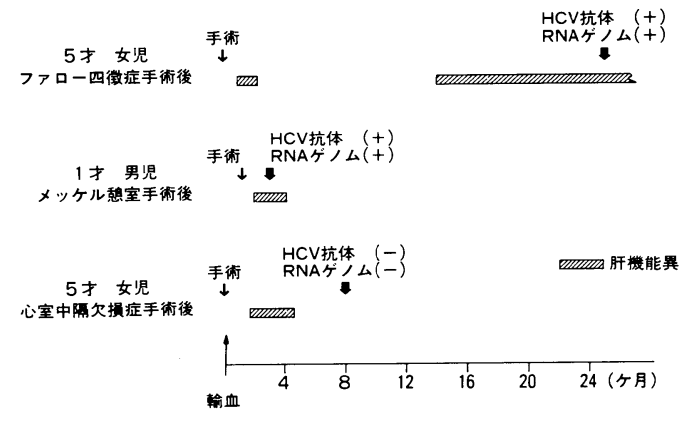

図 1 経過（輸血例）

経過（非輸血例）

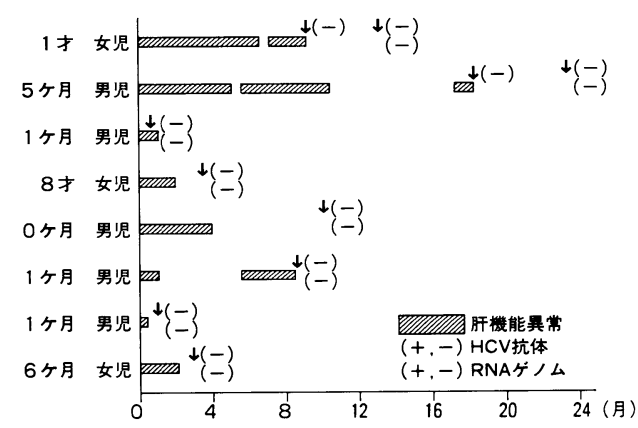

図 2 経過 (非輸血例)

(GPT で50IU/1以上) の有無により 2 群に分けると 肝機能異常を認めた群15例では抗体, ゲノムの両者 陽性例はなく，抗体のみ陽性が 1 例 $(6.7 \%)$ ，ゲノ 么のみ陽性が 5 例 $(33.3 \%)$, 両者陰性が 9 例（60.
表 2

肝機能異常あり：15例

\begin{tabular}{c|c|c}
\hline & HCV 抗体 $(+)$ & HCV 抗体 $(-)$ \\
\hline RNA ゲノム $(+)$ & 0 & 5 \\
\hline RNA ゲノム $(-)$ & 1 & 9 \\
\hline
\end{tabular}

肝機能異常なし：8例

\begin{tabular}{c|c|c}
\hline & HCV 抗体 $(+)$ & HCV 抗体 $(-)$ \\
\hline RNA ゲノム $(+)$ & 0 & 0 \\
\hline RNA ゲノム $(-)$ & 0 & 8 \\
\hline
\end{tabular}

(1\%)であった。一方，肝機能異常を認めなかった群 8 例では全例, 抗体, ゲノムともに陰性であった(表 2).

$$
\text { IV 症例 }
$$

以下に代表症例を呈示する。

【症例 1】1歳 8 力月の男児. S 58年に大量の下血 主主訴として入院し,へモグロビン $5.8 \mathrm{~g} / \mathrm{dl}$ と著明な 镍血を認めたため日本赤十字社の保存血 $200 \mathrm{ml}$ を輸 I血した。その後メッケル数室と診断され切除術を施 行した。輸血後2.5力月頃よりトランスアミナーゼの 上昇を認め約 6 力月で正常化した。輸血後 12 週目の 血清を検查したところ $\mathrm{HCV}$ 抗体抢よび RNA ゲノ ムともに陽性であり入院時の輸血によるC型肝炎と 洘えられた(図 3 ).

【症例 2】6 歳の女児. ファロー四徴症にて S 59年 に根治術を行い, この時に大量の輸血を受けた。 術 後 1 カ月頃, 発熱および300台程度のトランスアミ

\section{1 才 男児 メッケル数室手術後}

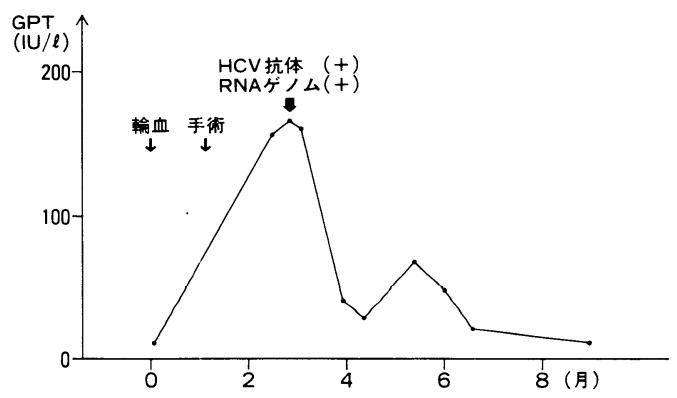

図31歳 男児 メッケル㴧室手術後 
5才 女児 ファロー四徴症手術後

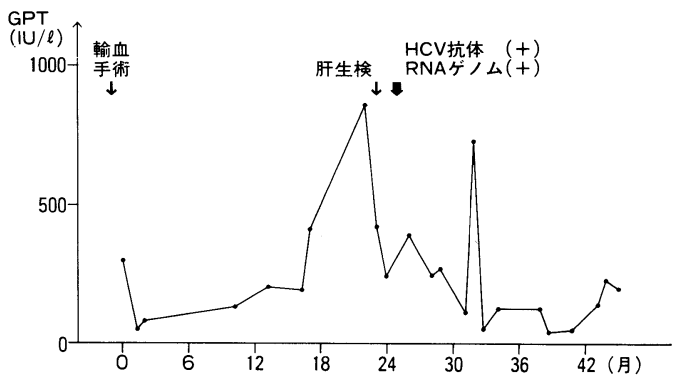

図45歳 女児 ファロー四徴症手術後

ナーゼの上昇を認め，その後 GPT 100〜200IU/1程 度の高値が現在まで続いている.S 61年3月には肝生 検を行い non-specific reactive hepatitis の所見で あった。本例も輸血後25力月目の血清にてC 型肝炎 ウイルス抗体および RNA ゲノムの両者陽性であり 輸血後のC型肝炎と考えられた（図 4 ）。

【症例 3 】 3 力月の男児. ALL の診断にて治療を開 始するとともに頻回に輸血を行った．治療および輸 血開始約 2 週間後よりトランスアミナーゼの上昇が みられ，1力月後には GPT 161IU/1，GOT 178IU/ 1まで上昇した。治療開始約 2 力月後の血清にて $\mathrm{HCV}$ 抗体陰性, RNA ゲノム陽性という結果を得た (図 5 ). 尚, 本例の受けた輸血はすべて日本赤十字 社で HCV 抗体のチェックを受けたものである.

\section{3ケ月 男児 急性リンパ性白血病}

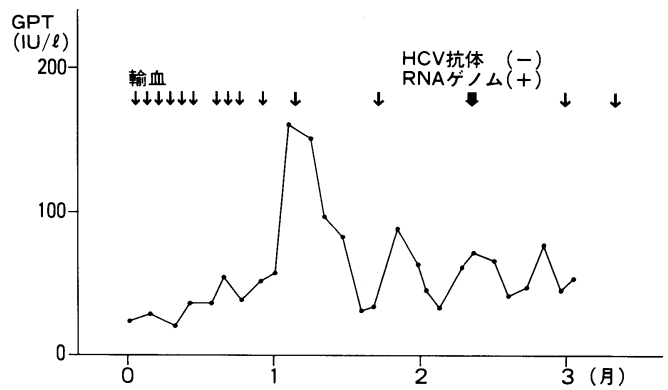

図５３个月＼cjkstart男児 急性リンパ性白血病

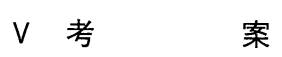

$\mathrm{HCV}$ 抗体は成人の非 $\mathrm{A}$ 非 $\mathrm{B}$ 型肝炎患者では
60〜 80\%の高值で陽性であると報告されている2, 3).一方，小児においては陽性率は低いとされ4)，本 検討でも陽性率 $18.2 \%$ であった。ただし，これを輸 血後肝炎という観点から考えると陽性率 $66.6 \%$ とな る. 同様の報告も既にいくつか見られている5,6). た今回の検討で非 A非B型肝炎の抗体陰性例は全例 ゲノムも陰性であった。したがって，小児で陽性率 が低いのは，抗体が疑陰性なのではなく実際にC 型 肝炎以外の原因による肝炎が多いからであると考え られた。

輸血既往のある血液疾患児例の検討では抗体とゲ ノムの結果の不一致が多くみられた。その原因とし ては，1．検査の感度や特異性の問題．2．抗原は すでに消失し抗体のみ残っている。 3 。血中に抗原 が存在していながらなんらかの理由で抗体が産生さ れない，あるいは産生が遅い，等が考えられる，代 表症例 3 にみられるように抗体陰性の血液を輸血し ているにもかかわらずゲノムが陽性化する例の存在 することは診断およびスクリーニングにおいて抗体 のみの測定で充分かどうかに疑問を残すものと思わ れた。

$$
\text { VI 結語 }
$$

1 ）小児の非 $A$ 非B型肝炎では成人に比べ HCV 抗 体陽性率は低い。

2 ) 小児の輸血後の非 $\mathrm{A}$ 非 $\mathrm{B}$ 型肝炎では成人と同程 度の陽性率である。

3) $\mathrm{HCV}$ 抗体と RNA ゲノムの不一致が多く見ら れた。

稿を終えるに当り，御校閲下さいました群馬大学小児 科学教室黒梅恭芳教授に深謝致します。

\section{文献}

1) Choo QL, Kuo G, Weiner $A$ et al: Isolation of a cDNA clone derived from a blood-borne non-A, non-B virus hepatitis genome. Science 244:359-362, 1989.

2) Kuo G, Choo QL, Alter $\mathrm{H}$ et al: An assay for circulating antibodies to a major etiologic virus of human non-A, non-B hepatitis. Science $244: 362-364,1989$.

3）飯野四郎, 倉井清彦, 日野邦彦ら：各種肝疾 患における Anti-HCV 抗体の陽性率について。 
肝臓, $30: 1643,1989$.

4）藤沢知雄, 鍵本聖一, 藤塚聡ら： 小児期の各 種肝疾患と HCV. 肝臟, 30：829, 1990 .

5）柴田睦郎, 富樫武弘, 成田光生ら：輸血歷を 有する各種疾患患児及び散発性非 $\mathrm{A}$ 非 $\mathrm{B}$ 型肝炎
患児のC型肝炎ウイルス抗体保有率. 日児誌, $94: 2257-2258,1990$.

6）長田郁夫, 原田友一郎, 岡田隆好ら：小肾輸 血後肝炎における Anti-HCV の検討. 肝臓, $30: 591,1990$.

\section{DETECTION OF ANTIBODIES TO C100-3 PROTEIN AND THE RNA SEQUENCES OF HEPATITIS C VIRUS IN CHILDREN}

\section{TETSUSHI OGAWA, TOSHIJI SHITARA, MANABU SOTOMATSU SHINICHIRO YUGAMI, KEN ITOH, TAKESHI TOMOMASA}

Department of Pediatrics, Gunma University

School of Medicine, Maebasini, 371, Gunma, Japan

(Director: Prof. Takayoshi Kuroume)

Blood samples taken from children with non-A, non-B hepatitis (NANBH) $(n=11$, Group 1) and from children with malignant disease and a history of frequent blood transfusions ( $n=$ 39, Group 2) were tested for the presence of antibodies to C100-3 and the RNA sequences of hepatitis $\mathrm{C}$ virus ( $\mathrm{HCV})$. The antibody was studied in all cases. The RNA was studied by means of the polymerase chain reaction in all cases of Group 1 and 23 cases of Group 2. Both antibody and RNA were detected in two out of the eleven children in Group 1, both of whom had recieved blood transfusions several months prior to the test. Neither antibody nor RNA was detected in the remaining cases in Group 1.

Antibody was positive in two out of the 39 Group 2 children, and RNA was positive in five out of 23. In Group 2, no cases were positive for both tests. An increase in blood GPT level was noted in all cases of Group 2 with positive results.

In conclusion, HCV infection is relatively rare in children of NANBH. There is a considerable discrepancy between the presence of antibody to C100-3 and the presence of RNA sequences.

Key words: Hepatitis C, C100-3, Non-A non-B hepatitis, Blood transfusion 